\title{
The Effect of Territorial Marketing on City Image Valuation: An Exploratory Study in Algeria
}

\author{
Zakia Megri $^{1} \&$ Fateh Bencherif ${ }^{2}$ \\ ${ }^{1}$ Faculty of Economic, Commercial and Management Sciences, Batna University, Batna, Algeria \\ ${ }^{2}$ APCL, Department of Industrial Engineering, Batna University, Batna, Algeria \\ Correspondence: Zakia Megri, Faculty of Economic, Commercial and Management Sciences, Batna University, \\ Algeria. Tel: 213-6-6815-4440, E-mail: megrizakia@yahoo.fr
}

$\begin{array}{lc}\text { Received: March 23, } 2014 \quad \text { Accepted: April 16, } 2014 \quad \text { Online Published: July 28, } 2014 \\ \text { doi:10.5539/ijms.v6n4p145 } & \text { URL: http://dx.doi.org/10.5539/ijms.v6n4p145 }\end{array}$

\begin{abstract}
This study aimed to determine the level of the valuation of the image and identity of Batna as historic, traditional, revolutionary city, with specific natural and cultural skills. The study also sought to identify the impact of marketing on the valuation of territorial identity and image of Batna. The study was conducted on a sample of 24 directorates representing all the actors in Batna city. We distributed 158 questionnaires to employees in these directorates, 135 were recovered, were valid for statistical analysis. After treatment and analysis of hypothesis using SPSS, it was ascertained the existence of a positive rating of the economic partners to apply the territorial marketing on Batna city as a touristic destination. The study concluded that there is an impact between the application of territorial marketing on Batna city and the valuation of the image and the city identity. The results show statistically significant differences in the application of territorial marketing in terms of its dimensions due to accept the presence of the partnership and to the fact that the concerned directorate is a main part.
\end{abstract}

Keywords: territorial marketing, touristic destination, city image, city identity, Batna city

\section{Introduction}

Territories and cities have seen a great development during the last two centuries. The first appearance of the territorial marketing was in Europe in 1875, where cities promote its touristic sites. The promotion of the cities consorts with the strategy that will evolve and become a major challenge for the territory. Territorial marketing appeared with the emergence of tourism. In order to understand the tourism development, some basics must be clarified. In the domain of marketing, territorial marketing enriches links between regional and urban economy, industrial economy, and tourism and business competitiveness.

Markets become completely competitive. The implementation of territorial marketing takes more attention of cities governors. Territorial marketing allows the application of new and useful methods, tools and applications contributing in improving the attractiveness, or the ability to attract attention, to the territories. The field of application of territorial marketing is so wide. Territorial marketing can be applied to a special project, such as large construction projects, special services, or an effort to group aims to strengthen the capacity of their own attractiveness of the territory. Territorial marketing is not a new concept, but remains as an idea worthy of being appear and clarify in its current application. Moreover, this approach allows an understanding of the meaning territory a more comprehensive manner, Also, to identify the actors in it, and face the challenges in territory and markets.

Today, the territorial marketing (place marketing) is an approach that aims to develop, based on knowledge of the environment (geographic, demographic, cultural, economic, social, political), territorial leaders offer by elected to a local government (city, county council, regional council) to ensure continuing suitability to various targets (tourists, residents, associations, companies, investors ...) while pursuing general interest missions of all their citizens and that, whatever the heterogeneity of identity elements that make up the territory they charge (Chamard \& Liquet, 2009). Territorial marketing lies at the confluence of three major marketing practices: product marketing, services marketing and social marketing and public (Avaraham \& Ketter, 2008). According to the application object, territorial marketing, and its specificities, is available in the work of Anglo-Saxon research under different names: Place branding (Selby et Morgan, 1996; Wai, 2006; Niedomysl, 2007) as regards 
the approach to develop the territory of a brand name, city branding (more rarely city marketing) for all approaches of marketing cities (Hetzel, 1998; Boland, 2008; Zhang \& Zhao, 2009; Brade et al., 2009) or the perceived cities image (Chamard, 2004) destination branding in the case of tourism initiatives aspiring to develop the attractiveness of a holiday image (Echtener \& Ritchie, 1993; Avaraham, 2000; Bradley et al., 2002; Konecnik et al., 2007; Boo et al., 2009).

The successful cities: New York, Paris, Amsterdam and San Francisco - had the qualities that strong brands do, and marketed their history, quality of place, lifestyle, culture, diversity, and formed cooperative partnerships between city municipalities and government in order to enhance their infrastructure. They were proactive in their approach (Winfield-Pfefferkorn, 2005). In Africa, Agadir, for example, working to upgrade its image and rise in composition to give the appearance of a harmonious with the city's streets through similar colors and shapes. The city needs all have the other factors outlined in this paper to work simultaneously in order to ensure a formula for city image success.

On this basis, the problem posed in this paper is based on the following question: Is the application of territorial marketing on Batna city, to valuate its identity and image and publicize it as a touristic destination, an idea that can make the most important actors in the city come to implement this project jointly?

In order to answer this question, we prepared a case study on a sample of the most active actors in Batna city. The sample size adopted in the study is 158 , distributed to a group of directorates in the city, and we get 135 interviews and analyzable forms.

\subsection{The Study Sought}

1) Understand the value of the image and the identity of Batna as historic, revolutionary, and traditional city with special natural and cultural skills.

2) Identify the impact of territorial marketing on the valuation of the identity and the image of Batna city.

\subsection{Study Hypotheses}

The study starts from the following hypotheses:

- Ho1: there is no impact relationship between the application of territorial marketing on Batna city (requirements, content, constraints), and the valuation of the image and identity of Batna.

- Ho2: there are no statistically significant differences of the application of territorial marketing, in terms of its dimensions due to global variables (presence of the partnership, and the fact that the directorate is a key party).

\section{Literature Review}

\subsection{What Is Territorial Marketing?}

Historically, according to Benoît Meyronin (2009), territorial marketing appeared in Europe with the emergence of tourist destinations at the end of the 19th century. The first stations that have been promoted in the regions are located on the side of the sea by various economic actors: Rail transport companies, property developer, hotels, municipalities, Etc. The first promotion of tourism was in France, and the first union promoter was created in France on 1900. The idea of attractiveness in a territory has become an avowed need, especially as the region itself has become more attractive to the targeted individuals formed by tourists. Thus the first strategies for territorial marketing were for the benefit of tourism promotion. According to Michel Ghetti, the general director of industry and employment of France, the territorial marketing in France was linked sharply with the decentralization of administration, and the French government administration (Pinal, 2010). The purpose of territorial marketing is to put a village, a city, or a region, on the national or the international market to increase the attractiveness and promote their development to attract a large number of tourists. Usually, territories look to confirm the differences existing among them to enhance communication and promotional campaigns. But these promotional campaigns lack for the study and analysis of the local identity and the absence of communication. And can be controlled through territorial identity, which is a way to give a distinct character and exploit attractive opportunities in order to differentiate itself from many territories (Dupé, 2007).

Accordingly, the territorial marketing is the activity to valuate lands in competitive markets in order to influence their audience's behavior to view the expected value of customers permanently and better than competitors. This activity usually managed by development agencies on behalf of public authorities or by actors from the private sector. It contains the input of territorial and urban economy, industrial and tourism economy, and work on competitiveness. In light of the competitive environment, the application and practice of territorial marketing has become a necessity. It allows providing methods and tools and useful ways to help improving the attractiveness of the region. But more importantly, the regional marketing translates a new case of aspirations and ambitions of 
regional officials to establish customer in the heart of the effort to adopt a set of methods and tools. The extent of territorial marketing is expanded by applying it to specific projects such as projects in large urban areas and some services or follows the global efforts to enhance the attractiveness of the region Vincent (Gollain, 2008).

Fabrice Hatem, defines territorial marketing as the activity to improve territory's share of the market within the framework of international trade flows and investment and skills. In general point of view, Hazel Valleguro defined territorial marketing as: the total of analysis, strategies, procedures and controls implemented by the urban management authority and organizations that have relied upon for this purpose, in order to meet the needs of individuals and activities within this territory. On the other hand it seeks to improve the quality and competitiveness of the city in the competitive environment (Gollain, 2008). The definition of Rosemberg-Lasorme look to territorial marketing as a communication tool between all the tools used to promote the territory image. As a result of this strategic endeavor, it can be said that the territorial marketing may resemble the marketing of products in the advertising image, promotion and media events. It is a new reality for many territories, and the outlines of these strategies remain vague and ambiguous (Rotureau, 2012). Marketing is applied to a territory by:

- Collection of tools and methods;

- territorial organization;

- Studies and capacities enhancement;

- Target audiences;

- Places of interest in territories;

- Behavior;

- Support and achieve the goals of territorial marketing.

In fact the advantage of using territorial marketing is to connect people together, residents and tourists. This requires the expectations of the division required by customers, but without neglecting the logic of sustainable development. There is no doubt that respect for the territorial identity by residents leads to enhance and strengthen the quality of tourism. Thus, the adoption of territorial marketing on identity gives it a strong competitive advantage which is difficult for competitors to imitate it.

The implementation of territorial marketing requires, in each territory, to ask a series of questions about the opportunities in the territory: who are your customers, how develop a suitable tourism, and how to maintain good relations with customers. The aim of territorial marketing is not only communication but also the strategic pursuit of the development of this territory. The strategy is a global vision directed to the organization's activities over the long term in order to gain a competitive advantage. That means that the strategic endeavor related to what can be offered by the territory and is mainly based on knowledge of local identity and territorial community.

Obviously, territorial marketing cannot establish or created without regard to the environment and characteristics of the territory. To develop a successful strategy, we should identify clear objectives that allow constructing a coherent strategy and performing procedures based on the scheme of the project (Rotureau, 2012). In this context, Hautbois and Desbordes offer many objectives of the territorial marketing as follows (Rotureau, 2012):

- Economic development;

- Tourism development;

- territorial Development;

- Awareness and reputation;

- Image;

- Highlighting territorial skills;

- territorial Promotion;

- Promote confidence with economic partners.

\subsection{From Territorial Marketing to City Marketing}

The city is the most important territorial unit. For since several years, many cities have seen an immense deterioration in various sectors. This deterioration is due to several reasons, including: technological progress, reception venues at low prices and strong competition between cities. Each city is trying to develop the industry 
and attract tourists. On the other hand it seeks to development and maintains its competitive advantage. This imposes to those interested and involved in this activity, to think about how to attract investment and development of the industrial sector and the tourism and success in communicating characteristics of the city to become an attractive pole for various target of this activity.

The territorial marketing is a modern concept and still under development. However, it evolves at a rapid rhythm as a result of the richness of the practices of managers who are trying to develop their regions as part of a consistent regional strategy. There is a variety of urban marketing practices, ranging from building policies to establish networks. And the use of signs, and the use of events, advertising in its various forms like press (web pages, press, posters ...), and social networking. Recently is appeared a new version of urban marketing so-called Off-shore, as Lyon-Dubai city project, which gives a value directly to the public moral capital of territories (Meyronin, 2009). The urban marketing is a practice divided into several distinct tendencies. In light of the available literature, Channoux and Serval (2011) note the presence of three tendencies:

1) Communicative urban marketing;

2) Strategic urban marketing;

3) Postmodern urban marketing.

These three tendencies are based on the evolution of the perception of the territory by urban marketing: from consider it as a place of production, to consider it as place of consumption. The communicative urban marketing has emerged during the $80 \mathrm{~s}$, and the goal was to re-evaluate the symbol or the name in relation with the meaning (Benoit \& Benoit, 1989), without the establishment of any strategic treatment. This marketing tries to sell regions as common products, using marketing tools without consistent and continuous process. It shows the territory as a product. Throughout this tendency, the goal is to promote the economic attractiveness of the territory. Thus, the territorial marketing was considered as a pillar to encourage the territory qualifications.

As a result of the change in the logic of competition between territories and the need for positioning, there was a transition to the strategic logic. During the mid-nineties, the territorial marketing took his place in the urban management to facilitate the positioning of any territory in a competitive market relative to other. However, the main challenge for strategic urban marketing is segmentation of targeted territorial public (Kotler \& Haider \& Rein, 1993).

Since 2000, urban marketing knew a new concept, in front of the complexity that occurred on the competitive level. Thus, the territory is not anymore just a supporting activity. But become a space in which people live and consume, and known as a collective context (Colletis-Wahl, 2008). Henceforth, the researchers were interested in the territory as a place of consumption, then all practices attempts to approach this concept (Warnaby \& Davies, 1997; Meyronin, 2009). Modern urban marketing phase influenced the evolution of modern marketing, which gives the importance of semantics and representations. Bringing the contemporary consumer seeks to total implication in an original experience (Cova, 2004). Under these concepts, the territory seeks to attract consumers who consume in the territory (Ingallina \& Park, 2005). The concept of consumption is changing, and become seen as entertainment (Ingallina \& Park, 2005). Lipovetsky (2004) talks about Consumption of pleasure, and Ingallina and Park (2005) deepen this idea, and confirm that the urban spaces of consumption are the product of new consumers' behaviors, as places producing culture, entertainment and a variety of other things with a high level of complexity. It should be noted that the recent trend of urban marketing taking shape through the activation of the territory and the impact of the location mark.

Meyronin (2006) explains that urban marketing knows new trends such as: renewal of urban spaces, which proposes new areas that reflect the different experiences with varying degrees of: entertainment, shopping, culture, and the creation of poles of excellence. They are trying to provide a space of "All in One". Thus, we do not need to segment the market, and therefore, the city is moving toward more consumption than production. Through these concepts, the urban marketing strategy tends towards the concept of brand image. Nowadays, contemporary urban marketing seeks to identify, describe, and control the image of the place.

The concept of city marketing revolves around the promotion of the city or a specific territory in order to encourage some activities carried out there. It is used to change the foreign perceptions of city in order to promote tourism and attract inward migration or enable the transfer of the business. The development of cities as a product can be marketed led to competition on investment and government funding. This often manifests itself in a bid of cities to attract international sports events like the Olympic Games. The city marketing is also known as the promotion for a city or an area in order to encourage activities of brand related to the city. Where they are exploited to change foreign perceptions about the city and attract tourists and investments. 


\subsection{Target Audiences in Territorial Marketing}

For the application of a coherent strategic effort, it must first determine the territory objectives. It is impossible to determine the territory objectives without taking into account the visitors who want to be hosted. The main goal allows establishing a clear and understood strategy by all actors. Since more than fifteen years, territorial authorities fought a battle to earn these three strategies to maintain competitiveness. Which explains the emergence of territorial communication, where each province highlight its strengths, and highlighted. Thus, cities require to study a class of audience to be hosted, and must designate the target markets that can be organized in accordance with the strategic objectives, the employment priorities, and projects in a matrix or in a tree interrelated (Rotureau, 2012).

We will rely on the work of Houtbois and Desbordes, they identified three categories of audiences as target: companies, families, and tourists. Every audience is different from the other so we cannot adopt the same strategy. The companies are the basis of the dynamic regional because it will lead to the prosperity of the local economy. That leads to the promotion of employment and increasing wealth in the region. For this target, the geographical positioning is the key implementation. If the territory provides offers and facilities for transportation, it will be an important option for companies that will influence the evolution of the market and the reputation and vision of cities. However, the attractiveness of the territories also limited to residential and tourist attraction, and the attractiveness of potential customers (residents, tourists, consumers) and other geographic markets (Rotureau, 2012).

For the second targeting, families, the territories will look to convince the public to work on its territory. This targeting is a complement to the first targeting. In fact, residents tend to live in places close to their work, and are also looking for places which provide them many activities and services. For example, the availability of schools or kindergartens or having a quick means of transportation, all these factors will make it easier for the population to live in that city.

Regarding the third Target, tourists, who are the main causes of the emergence of competition between territories, seeking to attract masses of seasonal to boost the economy at certain times of the year. The tourism global economy makes many tourist cities a major economic issue, territories are trying to collect more of the possible means to become an attractive destination and win a large number of this category.

Based on the idea of "territory - product", various territorial marketing targeting can be distinguished by two categories as: the internal targeting that includes all of the population, institutions, services, merchants, associations, universities and students; the external targeting includes new residents, tourists, participants in conferences and exhibitions, saloons, seminars, visitors to major events, business owners, students, carriers of information describing the ambassadors and the press (Dupé, 2007). These two categories create two types of approaches of territorial marketing. The first is specialized in internal marketing. The second is interested in external marketing.

\subsection{The Link between City Identity and City Image}

Metaphorically, the image is a reflection in the minds of the targeted audience to identify the city brand. This approach is the dominant in cities marketing. Identity is known as "a specific links that the manager aspiring to create, maintain, and identify a set of values linked to the city". These values are consistent with what they are in reality (Aaker, 1996). The need requires to attract tourists to a particular city to the success of building factories and companies, and to recruit and keep talented people and competent, or assistance on the sale and export of local products. The city must to recognize the main competitors (other cities or territories), and the adoption of a strategy able to deliver value. This strategy is based on the management of brand image, which means two main components:

1) Identify the target audience;

2) Find points of image and a strong and distinct positioning.

The idea of image is taken as a complement framework to the identity on the large-scale in territorial marketing practices. Therefore, there must be lighting for postural thought in order to move conjectures. It comes from the idea that makes the image a distorted reflection of the city identity. It is based on a debatable theoretical approach. It is an idea rooted and inspired by the behavioral world. The brand identity is attributed, according to this approach, to the principle of issuance and is mainly institutional. While the image is due to the principle of receiving and appearance, the two concepts are separate. Communications works to reduce the distance between them. The perception of identity is through the communication channels as a mediator. If the communication channels are effective enough, the content passes correctly to recipients. Good communication is a good image, 
because it is close to the identity. However, between the two and the message subject to the process of encoding, decoding, as well as the noise that might disturb it. Thus, managers must work hard to deliver, as much as possible of effectiveness, brand identity for its future audience, a way that avoids noise and coding errors, which may lead to the incorrect perception of identity. This means, the connection values and project brand through tools such as advertising, direct marketing and marketing events, for example. The recipient is included, in this case, the possibility of interpretation. When the received image is not corresponding with identity designed by managers, this indicates that there is an error in interpretation. This inevitably leads to address the problems of urban marketing, and giving technical answers to help in the development of communication policy at the best possible way.

The practice based on the image faces several risks, like exaggeration in identity determination, or vulgarity in studies of urban image. In some cases, these images are supported by the city's residents. The accent of Marseille or Toulouse, make it the pink city or the so-called "romantic Parisian", and a lot of myths, as believed Barthes (1957), has made marketing experts feel obligated to return to it. It's the identity that is shown here, and is widely present in a shared image (Rosemberg, 2000). This produces a distorted image and a fixed identity, which similarly returned without trouble until it is renewed in a very dynamic environment.

The concepts of identity and appropriate image in the context of the brand, becomes difficult to deal with in a territorial scale. However, to confront this difficulty, we will try, to raise this issue with another way. Therefore, any practice of territorial marketing on the basis of the relationship "identity-image", does not seem to be satisfactory. This leads to two raised issues: the first is about determining the virtual image of the city, and the second is related to work on a single image, including communication techniques. We ask the question as to whether the identity is determinable. Whereas, what is interesting is what moves, and makes the city in movement. Thus, it transforms continuously the identity, which makes the identity indefinable and elusive. The strong desire to control the image may make us forget that "Identity is the act or effort that can be identified by its effects".

\section{Case Study}

To overthrow the theoretical side to data and concrete facts, this study will identify the reality of marketing orientation in the territory of Batna city for the most important economic partners through various directorates and its impact on the valuation of image and city identity.

\subsection{Methodological Framework}

\subsubsection{Study Model Proposed}

To answer the research questions and achieve the purpose of the study, we build a holistic model to diagnose the extent of the applicability of regional marketing to identify Batna city as a tourist destination. The model includes two variables:

- The independent variable: territorial marketing (requirements, contents, and constraints or difficulties);

- The dependent variable: valuation of the image and the identity of Batna city.

The questionnaire is one of the most commonly used statistical tools to collect necessary information to achieve the objectives of the study. To this end, the list of survey is designed, which consists of two parts: the first contains data on the demographic characteristics of study sample (directorate, type, age, position, and years of experience, etc.), while the second parts includes questions that represent different dimensions of the variables of the study (independent and dependent variable). We used quintet Likert scale to measure the responses of the respondents. The questionnaire was organized and analyzed using SPSS (Statistical Package for the Social Sciences v20).

\subsubsection{Sample and Society of the Study}

The study society consists of the most important partners in Batna city as follow: directorate of tourism and handicrafts, conservatory of forest, directorate of environment, directorate of Culture, directorate of trade, directorate of university services, Batna university, directorate of agriculture, directorate of social activity, directorate of programming and budget monitoring, directorate of education, directorate of transportation, chamber of crafts, national security, directorate of Industry - small and medium enterprises and investment promotion, municipal people's congress, directorate of energy and mines, the department (Daira), directorate of building and construction, directorate of housing and public equipment, radio of Batna, department (Wilaya), directorate of health and population, and directorate of youth and sports.

Sample was taken from members of society who can be identified; we take the directorates previously mentioned. 
The sample size adopted in the research is 158 , distributed to the directorates previously mentioned, where it was retrieved 135 valid form of analysis, 135 analyzable forms were recovered.

\begin{tabular}{|c|c|c|}
\hline \multicolumn{3}{|c|}{ Independent variable: Territorial Marketing } \\
\hline $\begin{array}{l}\text { Requirements of Territorial Marketing } \\
\text { Application } \\
\text { 1- The need to re-distribution of human } \\
\text { resources between cities, Based on problems } \\
\text { presented and the programs offered. } \\
\text { 2- Programs take into account the } \\
\text { specificities and peculiarities of the size of } \\
\text { cities. } \\
\text { 3- Mobilization of real estate and rural } \\
\text { housing support. } \\
\text { 4- Strengthening of the road network } \\
\text { 5- Work on the creation of income- } \\
\text { generating activities }\end{array}$ & $\begin{array}{l}\text { The contents of Territorial } \\
\quad \text { marketing }\end{array}$ & $\begin{array}{l}\text { Difficulties in the application of } \\
\quad \text { Territorial marketing } \\
\text { 1- The weakness of the financial resources } \\
\text { allocated. } \\
\text { 2- Non-updating mechanisms of urban } \\
\text { planning with the current requirements of } \\
\text { the city. } \\
\text { 3- Delays in the approval of sectorial } \\
\text { development designs for the city by some } \\
\text { mistrial sectors. } \\
\text { 4- Devote the central policy decision- } \\
\text { making, and lack of activation of } \\
\text { decentralization. } \\
\text { 5- The absence of legal texts interval in the } \\
\text { case of overlap between the sectors. } \\
\text { 6- The difficulty of filling the real estate } \\
\text { container to bring investment. }\end{array}$ \\
\hline $\begin{array}{l}\text { The dependent va } \\
\text { Promoting Batna city as a touristic d } \\
\text { Its Identity, and its historical and civ } \\
\text { Its Identity, and its Religious image } \\
\text { Its Identity, and its cultural and socia } \\
\text { Its Identity, and its industrial image } \\
\text { Its Identity, and its environmental im }\end{array}$ & $\begin{array}{l}\text { able: Valuation of the image } \\
\text { tination both locally and interr } \\
\text { zation image compared to the } \\
\text { mpared to the rest of Algeria c } \\
\text { mage compared to the rest of } \\
\text { mpared to the rest of Algeria c } \\
\text { compared to the rest of Alg }\end{array}$ & $\begin{array}{l}\text { Id the city identity: } \\
\text { ionally due to: } \\
\text { t of Algeria cities; } \\
\text { es; } \\
\text { geria cities; } \\
\text { es; } \\
\text { a cities. }\end{array}$ \\
\hline
\end{tabular}

\subsubsection{The Stability of the Measurement Tool}

To check the reliability of study tool, Cronbach's Alpha factor was used; the degree of reliability is 0.88 . This value is higher than the accepted value $(0.60)$, it is acceptable for the purposes of scientific research, and this shows that the questionnaire have a high degree of stability.

\subsection{Results of Statistical Analysis}

\subsubsection{Sample Characteristics}

Descriptive statistics were used to extract the frequencies and percentages for the questions of the first section of the questionnaire that concern demographic characteristics. What can record as results is: Age group (25 to 35 years old) is the highest, reaching $56.3 \%$ of the total study sample. We record the lowest rate at category (less than 25 years old) with a rate of $5.9 \%$. The percentage of males in the study sample is $52.6 \%$, while the highest percentage of seniority in the organization is $43 \%$. With regard to the post it was observed that the highest percentage reach $74.1 \%$ involving staff, followed by heads of services to $13.3 \%$. Then comes the post of Head of department with $6.7 \%$, following this category with close rates of $3.7 \%$ and $2.2 \%$ as director and vice director, respectively, because most directorate do not contain the deputy director.

The study shows that $80.7 \%$ of the participant in the survey agrees to consider their organization as partner with the most important economic partners, in the marketing of Batna city as a tourist destination. And $72.6 \%$ agree to be considered as an essential institution in this partnership, and this explains staff awareness of the active role played by the institutions for the city's definition. 


\subsubsection{Test of the First Main Hypothesis}

In order to test the ability of the model on the interpretation, we used: correlation coefficient $\mathrm{R}$, the coefficient of determination R2, Average coefficient of determination R-2, that provides a more accurate interpretation because of the presence of more than one independent variable, and this is shown in the following table:

Table 1. Summary regression model

\begin{tabular}{llll}
\hline $\begin{array}{l}\text { correlation } \\
\text { coefficient R }\end{array}$ & $\begin{array}{l}\text { The coefficient of } \\
\text { determination -R2 }\end{array}$ & $\begin{array}{l}\text { Average coefficient of } \\
\text { determination -R-2 }\end{array}$ & standard error \\
\hline 0.48 & 0.23 & 0.21 & 0.68 \\
\hline
\end{tabular}

Table 2. Regression Analysis of Variance (ANOVA)

\begin{tabular}{llllll}
\hline & $\begin{array}{l}\text { Total square } \\
\text { variation }\end{array}$ & $\begin{array}{l}\text { Degrees of } \\
\text { freedom }\end{array}$ & $\begin{array}{l}\text { Average square } \\
\text { variation }\end{array}$ & $\begin{array}{l}\text { Value } \mathrm{F} \\
\text { Calculated }\end{array}$ & Level of significance \\
\hline Regression & 18.40 & 3 & 6.13 & 13.00 & 0.000 \\
Residuals & 61.35 & 130 & 0.47 & & \\
\hline Total & 79.76 & 133 & & & \\
\hline
\end{tabular}

Table 1 shows that, the correlation coefficient is 0.48 , which indicates the existence of a correlation between the medium of all independent variables (requirements, Contents and constraints of regional marketing) and the dependent variable (Valuation of image and identity of the city). The value of the determination coefficient (R2) is 0.23 . This means that the independent variables together explain $23 \%$ of the variance in the dependent variable. The rest of the variance is estimated at: 77, is attributed to other factors unstudied. Table 2 shows that the value of $F$ is estimated at 13.00 , and the corresponding value of the calculated level of significance is 0.00 . Therefore, the value of $\mathrm{F}$ is statistically significant, this means; rejecting the null hypothesis and accept the alternative hypothesis based on an impact relationship between the application of territorial marketing on Batna city and the valuation of image and identity of the city.

The test F may be misleading, because it tests the significance of the overall model. In order to test the partial hypotheses, the test $\mathrm{T}$ was adopted to test the significance of parameter of the model, each separately, at the level of significance $\alpha=5 \%$, the table below illustrates this results.

Table 3. Test of significance of regression coefficients according to the statistical $\mathrm{T}$

\begin{tabular}{llllll}
\hline Data & $\begin{array}{l}\text { B Regression } \\
\text { coefficient }\end{array}$ & standard error & BETA & T & Level of significance (SIG) \\
\hline Constant & 0.37 & 0.64 & $/$ & 0.57 & 0.56 \\
Requirements & $0.66-$ & 0.13 & $0.04-$ & -0.46 & 0.64 \\
Contents & 0.75 & 0.16 & 0.42 & 4.59 & 0.000 \\
Constraints & 0.14 & 0.08 & 0.14 & 1.75 & 0.08 \\
\hline
\end{tabular}

In order to interpret the results in Table 3, we must precisely, detail the partial hypotheses to be tested, as follow:

The first sub-hypothesis: There is no impact relationship between the application requirements of territorial marketing on Batna city, and the Valuation of the image and identity of Batna.

Table 3 shows that the value of the regression coefficient for the independent variable (requirements) is: -0.66 , and the corresponding standard value is: -0.04 . The Corresponding value of $\mathrm{T}$ is: -0.46 , which is not statistically significant, the value of the calculated level of significance (SIG) is: 0.64 , which is greater than the approved level of significance 0.05 . That means accepting the null hypothesis, which states that there is no impact relationship between the application requirements of territorial marketing on Batna city, and the Valuation of the image and identity of Batna.

The second sub-hypothesis: There is no impact relationship between the application contents of territorial marketing on Batna city, and the Valuation of the image and identity of Batna. 
Table 3 shows that the value of the regression coefficient for the independent variable (contents) is: 0.75 , and the corresponding standard value is: 0.42 . The corresponding value of $\mathrm{T}$ is: 4.59 (statistically significant). The value of the calculated level of significance (SIG) is: 0.000 , which is less than 0.05 . This means reject the null hypothesis and accept the alternative hypothesis which states: the existence of an impact relationship between the application contents of territorial marketing on Batna city, and the Valuation of the image and identity of Batna.

The third sub-hypothesis: There is no impact relationship between the application constraints of territorial marketing on Batna city, and the Valuation of the image and identity of Batna.

We note from Table 3 that, the value of the regression coefficient for the independent variable (constraints) is: 0.14 . The corresponding standard value is: 0.14 and the corresponding value of $T$ is: 1.75 , which is not statistically significant. The value of the calculated level of significance (SIG) is: 0.08 , which is greater than the adopted value of significance level (0.05). This means accepting the null hypothesis, which states that: There is no impact relationship between the application constraints of territorial marketing on Batna city, and the Valuation of the image and identity of Batna.

\subsubsection{Testing the Second Main Hypothesis}

Test of first sub-hypothesis: There are no statistically significant differences of the application of territorial marketing, in terms of its dimensions due to the presence of the partnership.

Table 4. Regression variance analysis of ANOVA of Partnership acceptance variable

\begin{tabular}{llllll}
\hline & $\begin{array}{l}\text { Total square } \\
\text { variation }\end{array}$ & $\begin{array}{l}\text { Degrees of } \\
\text { freedom }\end{array}$ & $\begin{array}{l}\text { Average square } \\
\text { variation }\end{array}$ & $\begin{array}{l}\text { Value } \mathrm{F} \\
\text { Calculated }\end{array}$ & $\begin{array}{l}\text { Level of } \\
\text { significance }\end{array}$ \\
\hline Regression & 0.10 & 2 & 0.55 & 3.57 & 0.03 \\
Residuals & 19.94 & 129 & 0.15 & & \\
\hline Total & 21.05 & 131 & & & \\
\hline
\end{tabular}

Table 4 shows that, the value of $\mathrm{F}$ is estimated at 3.57 and the value of the corresponding level of significance is 0.03 , i.e., the value of $\mathrm{F}$ is statistically significant, this means, the reject of the null hypothesis and accept the alternative hypothesis based on the existence of statistical significant differences in the application of territorial marketing in terms of its dimensions due to the presence of the partnership.

Test of second sub-hypothesis: There is no statistically significant differences of the application of territorial marketing, in terms of its dimensions due to the fact that the directorate is a key party).

Table 5. Regression variance analysis of ANOVA of "the directorate is a main part" variable

\begin{tabular}{llllll}
\hline & $\begin{array}{l}\text { Total square } \\
\text { variance }\end{array}$ & $\begin{array}{l}\text { Degrees of } \\
\text { freedom }\end{array}$ & $\begin{array}{l}\text { Average square } \\
\text { variance }\end{array}$ & $\begin{array}{l}\text { Calculated Value } \\
\text { of } \mathrm{F}\end{array}$ & significance Level \\
\hline \multirow{2}{*}{ Regression Residuals } & 1.16 & 2 & 0.58 & 3.78 & 0.02 \\
& 19.51 & 127 & 0.15 & & \\
\hline Total & 20.67 & 129 & & & \\
\hline
\end{tabular}

Table 5 shows that, the value of $\mathrm{F}$ is estimated at 3.78 , and the value of the corresponding significance level is: 0.02 , i.e., that the value of $\mathrm{F}$ is statistically significant. Therefore, reject of the null hypothesis and accept the alternative hypothesis, based on the existence of statistically significant differences in the application of territorial marketing in terms of its dimensions due to the fact that the concerned directorate is a main part.

\section{Results and Recommendations}

The study was done with the participation of 24 directorates in Batna city. The aim of this study was to find out the extent of the possibility of gathering the most important economic partners in the city to implement the project in a collective way. After viewing the field study on the promotion of Batna city as a tourist destination, and after treatment and analysis of hypothesis using SPSS, it was ascertained the existence of a positive rating of the economic partners to apply the territorial marketing on Batna city as a tourist destination. The study concluded a number of results, including: 
- The existence of an impact between the application of territorial marketing on Batna city and the valuation of the image and the city identity;

- The lack of the impact relationship between the requirements of the application of territorial marketing on Batna city and the valuation of the image and the city identity;

- The existence of an impact relationship between the contents of the application of territorial marketing and the valuation of the image and the city identity;

- The lack of the impact relationship between the constraints of the application of territorial marketing on Batna city and the valuation of the image and the city identity;

- The presence of statistically significant differences in the application of territorial marketing in terms of its dimensions due to accept the presence of the partnership.

- The existence of statistically significant differences in the application of territorial marketing in terms of its dimensions due to the fact that the concerned directorate is a main part.

Through this study, it is observed that the tourism sector is attractive and dynamic. If we exploit advantages of the interlace relationship with all other sectors, this will be reflected positively on the city. Algeria, despite what is owned in terms of resources, could not take niche in the global market. Through the study of the tourism sector, and the territory of Batna, in particular, we can set the following recommendations:

- Sensitization of the importance of the orientation towards the territorial marketing;

- Increase conscience of territorial marketing and its importance in the development of cities and territories;

- Activate the role of communications in tourism built on the basis of the image and identity of the city;

- Each territory should seek to identify the important places in the territory for the reinforcement and the development;

- Emphasis on the importance and the role that comes from the use of promotional methods on the city, such as newspapers, radio, the Internet and personal selling, etc.

- The importance of improving the city's image and identity and their advantages, in the definition of the distinctive places of the city;

- The interest in the development of infrastructure such as transportation and communications;

- The quest to make the city an attractive touristic destination, through the strengthening and promotion of all sectors of tourism, culture, industry, environment, etc.;

- The use of information and communication technology for the development of the city.

\section{References}

Aaker, D. A. (1996). Building strong brands. New York, NY: Free Press.

Avaraham, E. (2000). Cities and Their News Media Images. Cities, http://dx.doi.org/10.1016/S0264-2751(00)00032-9

Avaraham, E., \& Ketter, E. (2008). Media strategies for marketing places in crisis. United Kingdom: Butterworth-Heinemann Ed.

Benoit, J. M., \& Benoit, P. (1989). Décentralisation à l'affiche. La communication publicitaire des villes. Paris, France: Nathan/Agora/Ipsos.

Boland, P. (2008). The construction of images of people and place: Labelling Liverpool and stereotyping Scousers. Cities. http://dx.doi.org/10.1016/j.cities.2008.09.003

Boo, S., Busser, J., \& Baloglu, S. (2009). A model of cusomer-based equity and its application to multiple destinations. Tourism Management. http://dx.doi.org/10.1016/j.tourman.2008.06.003

Brade, I., Herfert, G., \& Wiest, K. (2009). Recent trends and future prospects of socio-spatial differentiation in urban regions of Central and Easterne Europe: A lull before the Storm? Cities. http://dx.doi.org/10.1016/j.cities.2009.05.001

Bradley, A., Hall, T., \& Harrison, M. (2002). Selling Cities: Promoting New Images for Meetings Tourism. Cities. http://dx.doi.org/10.1016/S0264-2751(01)00046-4

Chamard, C. (2004). L'évaluation de l'image de marque d'une ville: création d'une échelle de mesure du capital-citoyen, in Management Local, de la gestion à la gouvernance, Paris, France: Dalloz, Coll. Etudes. 
Chamard, C., \& Liquet, J. C. (2009a). L'évaluation de l'image perçue des régions françaises. Paper presented at the CNRS Conference, London, UK.

Chamard, C., \& Liquet, J. C. (2009b). L'impact d'un succès cinématographique sur l'image d'une région : le cas de "Bienvenue chez les ch'tis". Paper presented at the Congrès international de l'Association Française de Marketing, Londres, UK.

Chanoux, M., \& Serval, S. (2011). Etat des lieux et perspectives du marketing urbain: Une approche par la littérature. Laboratoire CERGAM, Marseille, France.

Colletis-Wahl, K. (2008). Micro-institutions et proximités: Quelles lectures des dynamiques territoriales? (pp. 251-264). Revue d' Economie Régionale et Urbaine, Paris, France. Abstract Retrieved from http://www.cairn.info/resume.php?id_article=reru_082_0251

Cova, B. (2004). Une pensée méridienne du marketing? Prospective pour un marketing méditerranéen (p. 23). Laboratoire Savoir Sud Euromed. Marseille, France.

Dupé, L. (2007). Le marketing territorial: un outil pertinent pour le développement local touristique et culturel. Master's thesis, University of Toulouse II - Le Mirail, France.

Echtner, C., \& Ritchie, B. (1993). The measurement of Destination Image: An Empirical Assessment.

Gollain, V. (2008). Réussir son marketing territorial en 9 étapes (p. 4). le club des développeurs économiques d'lle de France (Cdeif), Paris, France.

Hetzel, P. (1998). Le marketing des villes: concept éphémère à la mode ou tendance de fond pour repenser la relation entre élus et citoyens? in Maire, entrepreneurs, emploi, Paris, France : Dalloz, Coll. Etudes.

Ingallina, P., \& Park, J. (2005). City marketing est espaces de consommation: les nouveaux enjeux de l'attractivité urbain. Revue urbanisme, $\mathrm{n}^{\circ} 344$.

Konecnik, M. (2007). Customer-based brand equity for a destination. Annals of Tourism Research. http://dx.doi.org/10.1016/j.annals.2006.10.005

Kotler, P., Haider, D., \& Rein, I. (1993). Marketing Places. Attracting Investment, Industry, and Tourism to Cities. New York: States and Nations, Free Press.

Lipovetsky, G. (2004). Les temps hypermodernes. Paris, France: Grasset.

Meyronin, B. (2006). Marketing des services publics et marketing des territoires: vers une dynamique de ré-enchantement? Paper presented at the AIMS Conference, Rouen, France.

Meyronin, B. (2009). Marketing territorial, enjeux et pratiques (pp. 54-56). Paris, France: Vuibert.

Niedomysl, T. (2007). Promoting Rural Municipalities to Attract New Residents: an Evaluation of the Effects. Geoforum. http://dx.doi.org/10.1016/j.geoforum.2006.11.024

Pinal, A. (2010). Marketing Territorial et évaluation des évènements; La région Limousin et les évènements de la maison du Limousin à Paris. Master's thesis, University of Paris III: Sorbonne Nouvelle, Paris, France.

Rosemberg, M. (2000). Le marketing urbain en question, Production d'espace et de discours dans quatre projets de villes. Paris, France: Economica.

Rotureau, C. (2011-2012). En quoi l'événementiel sportif peut-il être un mode de valorisation par un territoire. Master's thesis, University of Paris-Sud, France.

Selby, M., \& Morgan, N. J. (1996). Reconstruing Place Image: A Case Study of its Role in Destination Market Research. Tourism Management. http://dx.doi.org/10.1016/0261-5177(96)00020-9

Wai, A. W. T. (2006). Place Promotion and Iconography in Shanghai's Xintiandi. Habitat International. http://dx.doi.org/10.1016/j.habitatint.2004.02.002

Warnaby, G., \& Davies, B. J. (1997). Commentary: Cities as Service Factories? Using the Servuction System for Marketing Cities as Shopping Destinations. International Journal of Retail and Distribution Management. http://dx.doi.org/10.1108/09590559710175953

Winfield, P. J. (2005). The Branding of Cities: Exploring city Branding and Importance of Brand Image. Master's thesis, Graduate School of Syracuse University, New York, USA.

Zenker, S., \& Braun, E. (2010). The place brand centre: A conceptual Approach for the brand Management of places. Paper presented at the $39^{\text {th }}$ European Marketing Academy Conference, Copenhagen, Denmark. 
Zhang, L., \& Zhao, S. X. (2009). City branding and the Olympic effect: A case study of Beijing. Cities. http://dx.doi.org/10.1016/j.cities.2009.05.002

\section{Copyrights}

Copyright for this article is retained by the author(s), with first publication rights granted to the journal.

This is an open-access article distributed under the terms and conditions of the Creative Commons Attribution license (http://creativecommons.org/licenses/by/3.0/). 